keep a bottle by him and recommend it to all his acquaintances. I have only cited a few of the more modest advantages that quackery presents to the layman. No doubt before long some king among quacks will advertise a panacea the regular consumption of which will not only cure every known disease and keep the body in sound health afterwards, but also mend socks, brush the dog, turn the cat out at night, and keep the canary supplied with groundsel. I feel sure there would be a run on it.

Now, Sir, what can the qualified offer in place of such attractions? If we are to snatch these frauds from the people we must provide them with some harmless substitute, and until we have settled what that substitute shall be, it is useless to proceed.

I am, Sir, yours faithfully,

August 13th, 1910.

F. H. PICKIN.

\section{ON THE NOTIFICATION OF CONSUMPTION.}

To the Editor of THE LANCET.

SIR,-With reference to Dr. R. Farquharson's article in THE LANCET of July 23rd and the reply by "Forensicus" to it in your issue of August 6th, I should feel obliged, with your permission, if "Forensicus" would reply to the following questions.

Before stating them I should like to say that it is not my intention to defend Dr. Farquharson against "Forensicus," believing that the former is eminently capable of performing that task for himself.

"Forensicus" has not disproved a single fact or controverted a single statement in Dr. Farquharson's article. He evades the issue by bestowing doubtful compliments and by appealing to authority, setting up one against another in order that he may gain that further knowledge he so earnestly desires. He displays a knowledge of the subject somewhat above that of the ordinary layman, nevertheless one perceives the hand of an Esau with the voice of a Jacob behind his letter. He believes that compulsory notification is an essential factor if a successful campaign against consumption is to be waged, and thinks the putting into force of a resolution such as that drafted by the public health authorities of the Rochdale union, and cited by him, would be the best means to that end.

These are my questions: 1 . If compulsory notification of consumption implies the subsequent control and supervision of the subject, how is this to be carried out, and what are the special regulations the consumptive must comply with and observe in public and private life? 2 . What action would the authorities take in the case of a consumptive who was under the care of a private medical practitioner and who at the same time was able and desirous to follow his business or supervise same; or in the case of a person in private life? 3 . When would the authorities cease to control and supervise the consumptive?

Granting in each case that the hygienic condition of the consumptive's home was such that he could be treated there, or such as would enable him to carry out a mode of life essential to him after he had undergone treatment.

I am, Sir, yours faithfully,

J. CunningmaM Bowie, M.B. Glasg., D.P.H. Cardiff, August 8th, 1910.

\section{HEART PUNCTURE.}

To the Editor of THE LANCET.

SIR, - I am honoured by the interest shown by Dr. Alexander Morison in my paper on "Heart Puncture," which was published in THE LANCET of August 6th, and have much pleasure in meeting his request for additional details as far as I am able. Of course, the very nature of the case precluded elaborate observations with scientific precision, but I am completely satisfied that there was no pericardial flooding with blood from the puncture. The fact of this not being recorded is unfortunate, as it was kept in mind and looked for and dreaded. The heart, from an inch to the left of the nipple in its maximum distension, retracted almost immediately to the nipple line and never went further to the left again either before or after death. I state this with conviction, because I carefully mapped out the area of præcordial dulness before puncture with hammer and pleximeter, and marked the limits in blue pencil, and $I$ did the same after death and found complete similarity. The only explanation I can offer for the blood not getting down between pericardium and heart is the likelihood of there having been adhesions and no cavity existing, and this is in harmony with attacks of recurring præcordial pain the girl often had, though I never heard friction sounds nor diagnosed presence of fluid. With regard to the pulse, it will be remembered that I could not feel it either at wrist or zygomata just before puncture. After her relief it was perfectly regular and full but easily compressed, but I did not think it dicrotic till well on towards the end. The nails were easy to blanch by pressure at the tips, but a crescentic area at the nail-roots remained pink under considerable pressure, and so did the capillaries of the lips under the edge of a tumbler pressed against them. There was no capillary pulse, no water-hammer pulse, and no tache cétrébrale. These are all the additional items I can add which 1 can vouch for. There was no post-mortem examina. tion.

Aberdeen, August 15th, $1910 . \quad$ J. Waldace Milvit,

I am, Sir, yours faithfully, lay journals has made him apprehensive of the accusation of being privy to such publication. He asks us to state that he had no hand in the matter.-ED. L.

\section{BLIND MASSEURS FOR BERI-BERI PATIENTS.}

To the Editor of THE LANCET.

SIR,--My attention has been drawn to a paragraph, headed as above, in to-day's Times concerning the treatment of beri. beri at the Seamen's Hospital, Albert Docks, London, $E$, with which my name is connected. I wish to state that I have nothing to do with the treatment of cases of beri-beri at the hospital, nor have I heard of Swedish movements and massage being employed in the treatment of beri-beri.

I am, Sir, yours faithfully,

Harley-street, W., August 17th, 1910. JAMES CANTLIE,

\section{THE NATION AND THE NAVY. To the Editor of THE LANCET.}

SIR,-My connexion with the Royal Nary commenced many years ago, and I have continued in close touch with it ever since. I have such a confirmed conviction of the vital importance of the perfect efficiency of the executive officers of all ranks, that I beg to submit for discussion in your columns the problem how the greatest natural talent and the highest fighting abilities of the nation may be obtained for staffing His Majesty's ships of war.

Certainly the responsibilities of admirals and captains in a great naval war are far greater than those of judges, bishops legislators, or the heads of other departments of Government. Even if it be allowed that only very high physical, mental, and moral qualifications be necessary for the executive officers, of and above the rank of lieutenant, the great practical question arises: At what age should the raw material-the naval cadets-be selected for training as executive naval officers?

I have the highest opinion of the method of training the boys at Osborne College; and most sincerely do I wish that all our public schools and grammar schools gave similar training to all the boys who are physically and mentally fit for it. But I venture to suggest that the age of entry as naval cadet is far too low to permit of the fittest material being selected to fulfil the most onerous duties that any human beings can be called upon to perform--the naval defence of this Empire. We certainly do not select boys of 13 to train them specially to be our judges, bishops, doctors, poets, musicians, painters, and sculptors. Nor does any other naval power select boys for naval training at so low an age as we select our cadets. At least 90 per cent. of the medical and military men, heads of factories, railways, and mercantile firms would, $I$ believe, agree that it is almost impossible to ascertain by physical and educa tional examinations of boys of 13 years of age what they will turn out to be at 16 to 18 years of age, still less what will be their moral qualifications between 20 and 30 rears of age.

The influences of heredity, whether good or bad, are ofter undeveloped before the age of 13 to 15 , but nearly almays 